\title{
EVALUASI RENCANA PEMBANGUNAN JANGKA MENENGAH DESA (Studi Kasus Di Desa Lubuk Suli Kecamatan Depati VII Kabupaten Kerinci)
}

\author{
AFRIYANTI, SE., M.Pd \\ STIA Nusa Sungai Penuh \\ afriyanti777746@gmail.com
}

\begin{abstract}
ABSTRAK
Development is a process of social change with broad participation a society that is intended to achieve social and material progress (including increasing the amount of justice, freedom and other valued qualities) for the majority of the people through the greater control they have over their environment. To plan development is not to build ideas and future strategies only without considering the social, cultural, and community adoption ability to change, so a lot of planning has been successful in stimulating economic growth in the short term but failed in building social cohesion, resisting vulnerability and reinforcing the cultural value. In relation to this, the village development planning should be put in a comprehensive manner to bridge the development needs of the region, strengthening the sector and harmonization of development actors.This study aims to see how the results of the evaluation of the Middle-Term Development Plan of the village of LubukSuli, DepatiTujuh District, Kerinci 2018 district. This type of research is a qualitative descriptive approach. Sources of data in this study using interviews and documentation. the general aspects of planning and implementation are good enough.
\end{abstract}

Key words: Development Plan, Medium Term, RPJMDes

Pembangunan adalah suatu proses perubahan sosial dengan partisipatori yang luas dalam suatu masyarakat yang dimaksudkan untuk mencapai kemajuan sosial dan material (termasuk bertambah besarnya keadilan, kebebasan dan kualitas lainya yang dihargai) untuk mayoritas rakyat melalui kontrol yang lebih besar yang mereka peroleh terhadap lingkungan mereka. Perencanaan pembangunan tidak cukup membangun gagasan dan strategi ke depan tanpa mempertimbangkan kondisi sosial, budaya, dan kemampuan adopsi masyarakat terhadap perubahan, sehingga banyak perencanaan telah berhasil dalam mendorong pertumbuhan ekonomi dalam jangka pendek tetapi gagal dalam membangun kohesivitas sosial, daya tahan terhadap kerentanan dan memperkuat nilai-nilai kultural. Berkaitan hal tersebut, perencanaan pembangunan desa harus diletakkan secara komprehensif untuk menjembatani kebutuhan pengembangan wilayah, penguatan sektor dan harmonisasi para pelaku pembangunan. Studi ini bertujuan untuk melihat bagaimana hasil evaluasi Rencana Pembangunan Jangka Menengah desa Lubuk Suli Kecamatan Depati Tujuh kabupaten Kerinci 2018. Jenis penelitian ini adalah pendekatan deskriptif kualitatif. Sumber data dalam penelitian ini menggunakan wawancara dan dokumentasi. aspek umum perencanaan dan implementasi sudah cukup baik.

Kata kunci:Rencana Pembangunan, jangka menengah, RPJMDes 


\section{PENDAHULUAN}

Pembangunan daerah untuk menciptakan kesejahteraan masyarakat daerah merupakan tujuan utama dari Undang-undang nomor 32 Tahun 2004 Tentang Pemerintah Daerah. Keberadaan dari pada Undang-undang ini sebagai respon dari aspirasi berbagai daerah yang merasakan perlunya pendelegasian sebagian kewenangan pemerintah pusat kepada pemerintah daerah. Pendelegasian kewenangan tersebut sebagai upaya daerah untuk dapat berbuat lebih cepat dalam tahapan pembangunan daerah.

Undang-undang nomor 32 Tahun 2004 Tentang Pemerintah Daerah telah memberikan konsep otonomi dan desentralisasi yang terfokus pada sebagaian urusan yang semestinya dikelola pemerintah pusat kini setelah terbitnya Undang-undang nomor 32 Tahun 2004 Tentang Pemerintah Daerah maka sebagian urusan tersebut menjadi kewenangan pemeritah daerah. Pemerintah daerah provinsi, kabupaten dan kota saat ini memiliki anggaran finansial masing-masing yang termuat dalam anggaran pendapatan dan belanja daerah (APBD) berikut postur APBD yang terpola secara berbeda namun dengan asas proporsional.

Dengan semakin kuatnya keinginan pemerintah pusat terhadap terwujudnya pembangunan di daerah melalui konsep otonom dan desentralisasi maka kini telah menjadi tugas pemerintahan daerah untuk dapat meningkatkan pembangunan di berbagai belahan wilayah administrasi termasuk pada unit terkecil dari wilayah administrasi kabupaten/kota yaitu desa.

Pembangunan yang berbasis pedesaan diberlakukan untuk memperkuat fondasi perekonomian negara, mempercepat pengetasan kemiskinan dan pengurangan kesenjangan perkembangan antar wilayah, sebagai solusi bagi perubahan sosial, desa sebagai basis perubahan. Dalam realisasinya, pembangunan pedesaan memungkinkan sumber-sumber pertumbuhan ekonomi digerakkan kepedesaan sehingga desa menjadi tempat yang menarik sebagai tempat tinggal dan mencari penghidupan. Infrastruktur desa, seperti irigasi, sarana dan prasarana transportasi, listrik, telepon, sarana pendidikan, kesehatan dan sarana-sarana lain yang dibutuhkan, harus bisa disediakan sehingga memungkinkan desa maju dan berkembang.

Rencana Pembangunan Jangka Menengah Desa (RPJMDes) adalah rencana kegiatan pembangunan desa untuk jangka waktu 6(enam) tahun yang isinya terdiri visi dan misi kepala desa terpilih. Perencanaan pembangunan Desa disusun berdasarkan hasil kesepakatan dalam musyawarah Desa yang wajib dilaksanakan paling lambat pada bulan Juni tahun anggaran berjalan.

Dalam menyusun RPJM Desa, Pemerintah Desa wajib menyelenggarakan musyawarah perencanaan pembangunan desa secara partisipatif yang diikuti oleh Badan Permusyawaratan Desa dan unsur masyarakat Desa. Rancangan RPJM Desa paling sedikit memuat penjabaran visi dan misi kepala Desa terpilih dan arah kebijakan perencanaan pembangunan Desa dengan memperhatikan arah kebijakan perencanaan pembangunan kabupaten/kota.

Dalam penyusunan RPJM Desa mengacu pada RPJM kabupaten/kota yang memuat visi dan misi kepala Desa, rencana penyelenggaraan Pemerintahan Desa, pelaksanaan pembangunan, pembinaan kemasyarakatan, pemberdayaan masyarakat, dan arah kebijakan pembangunan Desa. RPJM Desa disusun dengan mempertimbangkan kondisi objektif Desa dan prioritas pembangunan kabupaten/kota. RPJM Desa ditetapkan dalam jangka waktu paling lama 3 (tiga) bulan terhitung sejak pelantikan kepala Desa. Disini terlihat betapa penting dan mendesaknya penyusunan RPJM Desa dalam pemerintahan dan pengelolaan pembnagunan suatu daerah. Setelah penyususnan RPJM Desa pemerintah desa di tuntut 
untuk melaksanakan dengan baik dan maksimal setiap program dan kegiatan yang telah di tetapkan pada rencana pembangunan jangka menengah desa tersebut.

RPJM Desa merupakan salah satu sumber masukan dalam penyusunan RPJM Kabupaten/Kota. Dan pedoman bagi pemerintah Desa dalam menetapkan Anggaran Pendapatan Belanja Desa (APBDes). RPJM Desa tidak bisa diubah secara sembarangan, baru bisa dilakukan perubahan atau di review ulang dalam hal: Terjadi peristiwa khusus, seperti bencana alam, krisis politik, krisis ekonomi, dan/atau kerusuhan sosial yang berkepanjangan; atau Terdapat perubahan mendasar atas kebijakan pemerintah, pemerintah daerah provinsi, dan/atau pemerintah daerah kabupaten/kota.

Fenomena yang terjadi sekarang ini masih banyak desa-desa yang terdapat di Indonesia yang belum mampu membuat RPJM Desa dengan cukup benar sehingga hasil yang di harapkan pemerintah tidak tercapai dengan baik. Fenomena ini juga terjadi di pemerintahan Desa Lubuk Suli yaitu :Belum jelasnya batas desa dan susahnya menentukan tata wilayah RT/Dusun, Sulitnya membawa hasil panen warga karna jembatan penghubung karna kurang layak dipakai, Belum maksimalnya peran dan fungsi kelembagaan yang ada, baik di tingkat desa maupun dusun. Dalam kegiatan pembangunan bidang pemberdayaan masyarakat sering kali tidak melibatkan masyarakat secara keseluruhan, tetapi di ikuti oleh orang terdekat perangkat desa saja, sehingga pembangunan tersebut tidak tepat sasaran.

Rumusan Masalah

1. Bagaimanakah Hasil Evaluasi dari Rencana Pembangunan Jangka Menengah Desa Lubuk Suli Kecamatan Depati Tujuh Kabupaten Kerinci ?

2. Faktor-faktor apa saja yang menjadi penghambat dan pendukung dari realisasi Rencana Pembangunan Jangka Menengah Desa Lubuk Suli Kecamatan Depati Tujuh Kabupaten Kerinci Tahun?

Tujuan penelitian

1. Mengetahui Hasil Evaluasi dari Rencana Pembangunan Jangka Menengah Desa Lubuk Suli Kecamatan Depati Kabupaten Kerinci.

2. Mengetahui Faktor-faktor apa saja yang menjadi penghambat dan pendukung dari realisasi Rencana Pembangunan Jangka Menengah Desa Lubuk Suli Kecamatan Depati Tujuh Kabupaten Kerinci.

\section{METODE PENELITIAN}

Pendekatan Penelitian

Penelitian yang termasuk dalam jenis penelitian kualitatif. Tujuan dari penelitian ini adalah mengungkap fakta, keadaan, fenomena, variabel dan keadaan yang terjadi saat penelitian berjalan dan menyuguhkan apa adanya. Penelitian deskriptif kualitatif menafsirkan data yang bersangkutan dengan situasi yang sedang terjadi, sikap serta pandangan yang terjadi di dalam masyarakat, pertentangan dua keadaan atau lebih, hubungan antar variabel, perbedaan antar fakta, pengaruh terhadap sesuatu kondisi."

Informan penelitian

Informan tersebut terdiri dari pihak-pihak yang berkaitan secara langsung dengan program rencana pembangunan jangka menengah desa (RPJMDes) di Desa Lubuk Suli. Kepala Desa Lubuk Suli, Badan Musyawarah Desa (BPD), Aparatur Desa dan Tokoh Masyarakat dan juga unsur-unsur masyarakat.

Teknik Pengumpulan Data 
Pengumpulan data penelitian ini peneliti akan menggunakan sejumlah teknik pengumpulan data yaitu;

1) Wawancara

Menurut (Bugin B, 2007). Wawancara merupakan komunikasi terhadap satu orang atau lebih dengan secara langsung atau tidak langsung melalui media maupun secara setruktur atau tidak setruktur. Teknik wawancara dapat tertutup maupun terbuka melihat dari narasumber yang memberikan informasi mengenai penelitian.

\section{2) Dokumentasi}

Menurut (Silalahi U, 2009) dokumentasi merupakan pengumpulan data mengenai halhal yang berupa catatan, transkip, buku, surat kabar, majalah, notulen, rapot, agenda dan sebagainya. Metode dokumentasi ini dimaksudkan untuk memperoleh data berdasarkan sumber data yang ada pada Proses Penyusunan Rencana Pembangunan Jangka Menengah Desa (RPJMDes) di Desa Lubuk Suli.

\section{HASIL PENELITIAN DAN PEMBAHASAN}

\subsection{Pembahasan RPJMDes}

\subsubsection{Bidang penyelenggaraan pemerintahan desa}

Berdasarkan indikator Permendagri no 114 tahun 2014 yaitu bidang penyelenggaraan pemerintahan desa merupakan salah satu unsur penting dalam proses kemajuan sebuah desa. Selain sebagai penggagas program-program desa, pemerintahan desa juga menjadi penggerak roda pembangunan desa. Untuk tercapainya hal tersebut, maka kegiatan penyelenggaraan pemerintahan desa juga harus terus dilaksanakan dan ditingkatkan.

Prioritas program pembangunan secara bertahap skala desa merupakan program Pembangunan yang sepenuhnya mampu dilaksanakan oleh desa. Kemampuan tersebut dapat diukur dari ketersediaan anggaran belanja desa, kewenangan desa dan secara teknis di lapangan, tersedianya sumberdaya yang ada di desa.

Hal ini sesuai apa yang disampaikan oleh Kepala Desa Lubuk Suli ketika diwawancara dengan penulis beliau menyampaikan tentang Penyelenggaraan Pemerintahan Desa, penyelenggaraan pemerintahan desa belum berjalan sesuai dengan kebutuhan masyarakat disebabkan banyaknya staf-staf desa belum mengerti opsinya masing-masing karna staf baru banyak yang dilantik. Kemudian ditambahkan oleh BPD Desa Lubuk Suli ketika diwawancara dengan penulis beliau menyampaikan tentang Penyelenggaraan Pemerintahan Desa, belum efektifnya regulasi desa, dalam mengatur pelaksanaan pemerintah desa dan kurangnya fasilitas operasional untuk pelaksanaan pemerintah desa. Kemudian ditambahkan oleh Kaur Pemerintahan ketika diwawancara dengan penulis beliau menyampaikan tentang Penyelenggaraan Pemerintahan Desa, penyelenggaraan pemerintah desa sudah sangat sesuai dengan kebutuhan masyarakat, karna sudah banyak aparatur pemerintahan yang tahu tugasnya masing-masing.

Dan adapun dari penyelenggaraan pemerintah desa tentang batas-batas desa yang disampaikan oleh Kepala Desa, Sudah ditetapkan namun, batas didusun belum dibentuk peta dan dipublikasikan ke masyarakat oleh sebab itu banyak masyarakat tidak mengetahui batasbatas desa lubuk suli. Mengenai batas-batas kami dari pemerintahan desa sudah menetapkan dan sudah disampaikan atau diberi tahukan kepada masyarakt desa lubuk suli.

Berdasarkan uraian hasil wawancara dengan informan diatas menurut analisa peneliti bahwa Tim RPJMDes Lubuk Suli (rencana pembangunan jangka menengah desa) sudah berjalan cukup baik tapi, masih banyak yang harus Ditingkatkan dari aparatur dan juga informasi. 
Sehingga semua kegiatan dapat diketahui oleh masyarakat desa. Dan diharapkan kepada tim RPJMDes dapat dipertahankan dan tingkatkan lagi sebagai penanggung jawab pelaksanaan RPJMDes.

\subsubsection{Bidang pelaksanaan pembangunan desa}

Berdasarkan indikator Permendagri no 114 tahun 2014 yaitu bidang Pelaksanaan pembangunan merupakan salah satu agenda yang terus dilakukan pemerintah Desa Lubuk Suli setiap tahunnya. Program-program pembangunan tersebut disusun untuk memenuhi kebutuhan masyarakat maupun lembaga-lembaga pemerintahan desa. Pelaksanaan pembangunan diawali dengan perencanaan serta perancangan melalui sebuah forum musyawarah desa yang melibatkan pemerintah desa, BPD, dan lembaga-lembaga masyarakat. Perencanaan pembangunan tentunya harus disesuaikan dengan aspirasi masyarakat, kebutuhan, serta peraturan yang berlaku.

Prioritas program pembangunan secara bertahap skala desa merupakan program Pembangunan yang sepenuhnya mampu dilaksanakan oleh desa. Kemampuan tersebut dapat diukur dari ketersediaan anggaran belanja desa, kewenangan desa dan secara teknis di lapangan, tersedianya sumber daya yang ada di desa.

Kewenangan desa dan secara teknis di lapangan, tersedianya asumber daya yang ada di desa. Hal ini sesuai apa yang disampaikan oleh Kepala Desa Lubuk Suli ketika diwawancara dengan penulis beliau menyampaikan tentang Pelaksanaan Pembangunan Desa:

Pembentukkan RPJMDesa telah melalui musdus (musyawarah dusun per dusun) dan telah ditetapkan diRPJMDesa selanjutnya kita melaksanakan untuk pembangunan tahun akan datang dilaksanakan musdes (musyawarah desa) untuk di bentukkan RKPDesa yang mengacu pada RPJMDesa jadi aspirasi masyarakat memang diambil dari musyawarah dusun.

Kemudian ditambahkan oleh BPD Desa Lubuk Suli Kecamatan Depati Tujuh ketika diwawancara dengan penulis beliau menyampaikan tentang Pelaksanaan Pembangunan Desa Pelayanan kepada masyarakat masih belum efektif dan efesien, mengingat sarana dan prasarana. Kemudian ditambahkan oleh Kaur Pembangunan Desa Lubuk Suli Kecamatan Depati Tujuh ketika diwawancara dengan penulis beliau menyampaikan tentang Pelaksanaan Pembangunan Desa masih minim mengingat desa-desa yang lainnya berlomba-lomba membangun desa menjadi lebih baik.

Dan adapun dari pelaksanaan pembangunan desa tentang pembangunan 2017-2018 terfokuskan kepada gedung sanggar seni yang disampaikan oleh Kepala Desa bidang pembangunan utuk pembangunan gedung desa lubuk suli sengaja di bangun gedung sangar seni untuk potensi-potensi yang ada pada pemuda dapat tersalurkan karna kalau tanpa ada kegiatan, pemuda akan menjurus ke kegiatan yang negatif. Kemudian ditambahkan oleh BPD menyampaikan tentang pembangunan 2017-2018 terfokuskan kepada gedung sanggar seni. Dan adapun dari pemerintahan desa tentang kenapa jembatan/jalan usaha tani belum diperbaiki yang disampaikan oleh Kepala Desa sudah diperbaiki tetapi hancur setiap kali banjir, hal yang samadi sampaikan oleh BPD lubuk suli.

Berdasarkan uraian hasil wawancara dengan informan di atas menurut analisa peneliti bahwa Tim RPJMDes Lubuk Suli (rencana pembangunan jangka menengah desa) sudah berjalan cukup baik tapi, masih banyak yang harus Ditingkatkan dari aparatur dan juga informasi. Sehingga semua kegiatan dapat diketahui oleh masyarakat desa. Dan diharapkan kepada tim RPJMDes dapat di tingkatkan lagi sebagai penanggung jawab pelaksanaan RPJMDes.

\subsubsection{Bidang pembinaan kemasyarakatan}


Berdasarkan indikator Permendagri no 114 tahun 2014 yaitu bidang Pembinaan kemasyarakatan merupakan salah satu program pemerintah dalam meningkatkan serta mengelola lembaga dan sumber daya manusia agar lebih baik dan bekerja sesuai dengan harapan. Pembinaan kemasyarakat dapat dilakukan dengan berbagai cara baik melalui pelatihan, rapat, lomba, peringatan hari besar dan lain-lain.

Prioritas program pembangunan secara bertahap skala desa merupakan program Pembangunan yang sepenuhnya mampu dilaksanakan oleh desa. Kemampuan tersebut dapat diukur dari ketersediaan anggaran belanja desa, kewenangan desa dan secara teknis di lapangan, tersedianya sumber daya yang ada di desa.

Hal ini sesuai apa yang disampaikan oleh Kaur Kemasyarakatan Desa Lubuk Suli menyampaikan tentang Pembinaan Masyarakat Desa terfokus oleh peningkatan kapasitas aparatur desa dalam melayani kebutuhan masyarakat yaitu menigkatkan kapasitas untuk mengetahui tupopsi-tupopsi masing-masing agar masyarakat dalam melaksanakan admnistrasi desa berjalan sesuai yang dibutuhkan oleh masyarakat.

Kemudian ditambahkan oleh Lembaga Adat Desa Lubuk Suli menyampaikan tentang Pembinaan Masyarat Desa sudah sesuai dikerjakan dengan baik dan juga banyaknya pelatihan-latihan yang dilakukan. Kemudian ditambahkan oleh PKK Desa Lubuk Suli sudah sesuai yang tercantum dalam RPJMDesa dan juga sudah ada pelatihan yang di laksanakan dengan kebutuhan masyarakat desa.

Dan adapun dari pemerintahan desa tentang apa saja program Pembinaan Masyarakat yang disampaikan oleh Kaur Kemasyarakatan Desa Lubuk Suli Untuk kegiatan pembinaan masyarakat diperioritaskan pada aparatur desa yang mana untuk meningkat kapasitas aparatur desa kami melaksanakan pembinaan dibidang administrasi desa yaitu pelatihan dalam kegiatan pemahaman tentang komputer. Kemudian ditambahkan oleh PKK Desa Lubuk Suli menyampaikan tentang program Pembinaan Masyarakat Desa Pembinaan lembaga adat, pembinaan usaha tani, pembinaan perangkat desa dan pembinaan terhadap kelompok wanita.

Berdasarkan uraian hasil wawancara dengan informan diatas menurut analisa peneliti bahwa Tim RPJMDes Lubuk Suli (rencana pembangunan jangka menengah desa) sudah berjalan cukup baik tapi, masih banyak yang harus Ditingkatkan dari aparatur dan juga informasi. Sehingga semua kegiatan dapat diketahui oleh masyarakat desa. Dan diharapkan kepada tim RPJMDes dapat dipertahankan dan tingkatkan lagi sebagai penanggung jawab pelaksanaan RPJMDes.

\subsubsection{Bidang pemberdayaan masyarakat}

Berdasarkan indikator Permendagri no 114 tahun 2014 yaitu bidang Pemberdayaan masyarkat merupakan salah satu program pemerintah desa dalam memanfaatkan semua sumber daya yang ada agar dapat berkembang serta dapat membantu proses kemajuan desa. Sasaran dalam program pemberdayaan masyarakat ini mencakup semua bidang, mulai dari pemerintahan, kelembagaan, kesehatan, ekonomi masyarakat, teknologi, dan pendidikan.

Prioritas program pembangunan secara bertahap skala desa merupakan program Pembangunan yang sepenuhnya mampu dilaksanakan oleh desa. Kemampuan tersebut dapat diukur dari ketersediaan anggaran belanja desa, kewenangan desa dan secara teknis di lapangan, tersedianya sumberdaya yang ada di desa. Hal ini sesuai apa yang disampaikan oleh Kaur Kemasyarakatan Desa Lubuk Suli menyampaikan tentang Pembinaan Masyarakat Desa pembinaan masyarakat terfokus oleh peningkatan kapasitas aparatur desa dalam melayani kebutuhan masyarakat yaitu menigkatkan kapasitas untuk mengetahui tupoksi masing-masing agar masyarakat dalam melaksanakan admnistrasi desa berjalan sesuai yang dibutuhkan oleh masyarakat. Kemudian ditambahkan oleh Lembaga Adat Desa menyampaikan tentang Pembinaan Masyarakat Desa Kemudian ditambahkan oleh PKK Desa 
tentang Pembinaan Masyarakat Desa sudah sesuai yang tercantum dalam RPJMDesa dan juga sudah ada pelatihan yang sesuai dengan kebutuhan masyarakat desa.

Dan adapun dari pemerintahan desa tentang apa saja program Pembinaan Masyarakat yang disampaikan oleh Kaur Kemasyarakatan Desa Lubuk Suli Untuk kegiatan pembinaan masyarakat diperioritaskan pada aparatur desa yang mana untuk meningkat kapasitas aparatur desa kami melaksanakan pembinaan dibidang administrasi desa yaitu pelatihan dalam kegiatan pemahaman tentang komputer.

Berdasarkan uraian hasil wawancara dengan informan diatas menurut analisa peneliti bahwa Tim RPJMDes Lubuk Suli (rencana pembangunan jangka menengah desa) sudah berjalan cukup baik tapi, masih banyak yang harus Ditingkatkan dari aparatur dan juga informasi. Sehingga semua kegiatan dapat diketahui oleh masyarakat desa. Dan diharapkan kepada tim RPJMDes dapat dipertahankan dan tingkatkan lagi sebagai penanggung jawab pelaksanaan RPJMDes.

\subsection{Evaluasi RPJMDesa}

Dalam rangka pelaksanaan amanat Undang-Undang Nomor 25 Tahun 2004 tentang Sistem Perencanaan Pembangunan Nasional, Undang-Undang Nomor 17 Tahun 2003 tentang Keuangan Negara dan sesuai dengan pola pemikiran dimaksud di atas, maka sebuah desa diharuskan mempunyai perencanaan yang matang berlandaskan partisipasi dan transparansi serta demokratisasi yang berkembang di desa yang terangkum dalam Rencana Pembangunan Jangka Menengah Desa (RPJM-Desa). Hal tersebut merupakan rencana pembangunan strategis desa dalam waktu 5 (lima) tahun dan Rencana Kerja Pembangunan Desa (RKPDesa) yang merupakan Rencana Pembangunan Desa yang disusun untuk jangka waktu 1 (satu) tahunan berdasarkan penjabaran RPJM Desa, hasil evaluasi pelaksanaan Dokumen pembangunan tahun sebelumnya, prioritas kebijakan supra desa dan atau hal-hal yang karena keadaan darurat atau bencana alam. Sebagai rencana strategis pembangunan tahunan desa, RKP-Desa merupakan dokumen perencanaan pembangunan yang bersifatregulasi yang pada pelaksanaannya dilakukan oleh Pemerintah Desa, Badan Permusyarawatan Desa dan unsur masyarakat yang mempunyai tugas dan tanggung jawab pembangunan di desa. RKP-Desa merupakan satu-satunya pedoman atau acuan pelaksanaan pembangunan bagi Pemerintah Desa dalam jangka waktu 1 (satu) tahun yang selanjutnya dimasukkan dalam Anggaran Pendapatan dan Belanja Desa (APBDesa) tahun anggaran bersangkutan.

Sebagaimana menurut salah satu aparatur desa lubuk suli yaitu bapak Hamami Firdaus yang menjabat menjadi bendahara desa mengatakan tentang Evaluasi RPJMDes :sudah berjalan dengan baik, karena dalam realisasi kegiatan yang diterapkan dalam RKPDes mengacu pada RPJMDes yang talah ditetapkan sebelumnya dan dijabarkan di APBDes tahun 2018. Adapun menurut salah satu aparatur desa lubuk suli yaitu bapak Hamami Firdaus yang menjabat menjadi bendahara desa mengatakan tentang apa saja kesulitan Evaluasi RPJMDes Walaupun kegiatan dalam RPJMdes, tidak semua tercover. Seluruhnya namun tetap terealisasi. Evaluasi hasil pembangunan tahun sebelumnya dilakukan melalui analisa terhadap kesesuaian antara program dan kegiatan yang terdapat dalam Anggaran Pendapatan dan Belanja Desa (APBDesa) Tahun Anggaran 2018 dengan implementasi pelaksanaan pembangunan tahun 2019

\subsubsection{Pendapatan Desa}

Pendapatan desa sebagaimana meliputi semua penerimaan uang melalui rekening desa yang merupakan hak desa dalam 1 (satu) tahun anggaran yang tidak perlu dibayar kembali oleh desa. Perkiraan pendapatan desa disusun berdasarkan asumsi realisasi pendapatan desa tahun sebelumnya dengan perkiraan peningkatan berdasarkan potensi yang menjadi sumber 
Pendapatan Asli Desa, Bagi Hasil, Bagian Dana Perimbangan, Bantuan keuangan dari Pemerintah Pusat, Pemerintah Provinsi dan Pemerintah Kabupaten, Hibah dan Sumbangan Pihak Ketiga. Asumsi pendapatan Desa Tahun Anggaran 2018 yang bersumber dari : ADD dan DD.

\subsubsection{BelanjaDesa}

Belanja desa sebagaimana dimaksud meliputi semua pengeluaran dari rekening desa yang merupakan kewajiban desa dalam 1 (satu) tahun anggaran yang tidak akan diperoleh pembayarannya kembali oleh desa. Belanja sesuai dengan Peraturan Menteri Dalam Negeri Nomor 37 Tahun 2007 dan Bupati Kabupaten Kerinci Nomor 24 Tahun 2018 tentang Pedoman Pengelolaan Keuangan Desa meliputi Belanja Langsung dan Belanja Tidak Langsung.

\subsection{Faktor-faktor yang mendukung dan mempengaruhi}

\subsubsection{Faktor pendukung}

\section{Partisipasi Masyarakat}

Partisipasi Masyarakat adalah keterlibatan seseorang atau pun suatu kelompok (masyarakat) secara aktif dalam berkontribusi dengan sukarela pada sebuah program pembangunan, seperti terlibat dalam hal perencanaan, pelaksanaan, monitoring dan juga sampai evaluasi.

\section{Sarana dan Prasarana}

Sarana adalah segala sesuatu yang dapat dipakai sebagai alat dalam mencapai maksud atau tujuan. Sedangkan prasarana adalah segala sesuatu yang merupakan penunjang utama terselenggaranya suatu proses (usaha, pembangunan, proyek). Pada dasarnya, tujuan diadakannya perencanaan sarana dan prasarana adalah :

untuk menghadiri terjadinya kesalahan dan kegagalan yang tidak di inginkan.

untuk meningkatkan efektivitas dan efisiensi dalam pelaksanaannya.

\subsubsection{Faktor penghambat}

\section{Sumber Daya Manusia}

Sumber Daya Manusia merupakan faktor penting dalam proses pengelolaan Alokasi Dana Desa. Peran dan pentingnya Sumber Daya Manusia dalam Instansi Pemerintahan adalah bahwa segala potensi sumber daya yang dimiliki manusia yang dapat dimanfaatkan sebagai usaha untuk meraih keberhasilan dalam mencapai tujuan baik secara pribadi individu maupun di dalam instansi. Sumber daya tersebut meliputi tenaga dan kemampuan manusia (baik daya pikir serta daya fisiknya) benar-benar dapat dimanfaatkan secara terpadu dan secara optimal.

\section{Komunikasi}

Komunikasi adalah suatu proses penyampaian informasi (pesan, ide, gagasan) dari satu pihak kepada pihak lain. Komunikasi sangat penting dalam kehidupan manusia sebab komunikasi merupakan sebuah proses untuk menyampaikan maksud atau pesan yang menjadi tujuan kepada orang lain. Sehingga, jika manusia ingin menyampaikan apa yang ia maksudkan, ia harus berkomunikasi. begitu pula sebaliknya kita bisa memahami seseorang dengan melalui komunikasi. Namun realitas yang terjadi di Desa Lubuk Suli komunikasi merupakan faktor penghambat dalam melaksanakan pembangunan Desa. 


\section{SIMPULAN}

Bidang Penyelenggaraan Pemerintahan Desa Lubuk Suli masih belum memenuhi aspek dari masyarakat dikarenakan banyaknya perangkat desa belum mengetahui apa-apa saja yang dikerjakan. Bidang Pelaksana Pembangunan Pemerintahan Desa Lubuk Suli sudah cukup baik mengingat pembangunan-pembangunan sudah banyak yang dibangun sesuai kebutuhan masyarakat. Bidang Pembinaan Masyarakat Desa Lubuk Suli sudah di laksanakan sesuai dengan yang terdapat pada RPJMDes banyaknya pelatihan dalam pembinaan masyarakat. Bidang Pemberdayaan masyarakat Desa Lubuk Suli masih belum banyak melakukan pelatihan-pelatihan pemberdayaan masyarakat seperti pelatihan pemuda/pemudi, pelatihan kerajinan, pelatihan kelompok tani dan lain-lain. jadi untuk tahun yang akan datang diharapkan diperbanyak pelatihan untuk masyarakat.

\section{UCAPAN TERIMA KASIH}

1. Bapak kepala desa Lubuk Suli berserta Staf yang telah bersedia di wawancara.

2. Bapak ketua BPD berserta anggota yang telah meluangkan waktu untuk memberikan data yang di butuhkab penulis.

3. Bapak tokoh masyarakat dan unsur masyarakat yang telah bersedia menyediakan waktu untuk penulis.

\section{DAFTAR PUSTAKA}

Bungin, Burhan, 2017. Metodologi Penelitian Kualitatif. Jakarta: Raja Grafindo Persada Erick S, 2010. Pembangunan Desa. Jakarta. PT Raja Grafinda Persada.

Maisyuri, 2017, Evaluasi Penyusunan Rencana Pembangunan Jangka Menengah Desa. Jurnal Visioner \& Strategis Volume 6, No 2.

Silalahi U, 2009. Metode Penelitian Sosial. Bandung.PT Refika Aditama.

Sugiyono, 2018. Metode Penelitian (Pendekatan Kuantitatif, Kualitatif, dan R\&D). Bandung: Alfabeta.

Supeno, Wahjudin, 2011. Rencana Pembangunan Jangka Menengah Desa. Banda Aceh, The World Bank

RPKDesa Tahun 2018, Desa Lubuk Suli Kecamatan Depati Tujuh Kabupaten Kerinci.

\section{Peraturan dan Undang-undang}

Peraturan Pemerintah Republik Indonesia Nomor 43 Tahun 2014 Tentang Desa.

Peraturan Menteri Dalam Negeri Republik Indonesia Nomor 114 Tahun 2014 Tentang

Pengelolaan Keuangan Desa

Undang-Undang Nomor 32 Tahun 2004 Tentang Pemerintahan Daerah

Undang-Undang Nomor 6 Tahun 2014 Tentang Desa 